\title{
Earned Income Tax Credits and Labor Supply: New Evidence from a British Natural Experiment
}

\section{Andrew Leigh \\ Research School of Social Sciences, Australian National University, ACT 0200, Australia}

\section{National Tax Journal}

Vol. LX, No. 2

June 2007
Abstract - With many countries considering the adoption of a system of earned income tax credits, it is useful to analyze how different types of credits affect labor supply and earnings. This paper focuses on a 1999 reform to the UK tax credit system, which increased the value of the credit and reduced the phaseout rate. Using panel data, with individual fixed effects, I compare eligibles and ineligibles within five groups: all individuals; those whose demographic characteristics predict that they will have low earnings; single women; women in couples; and men in couples. Over a 15-month period, boosting the credit appears to have raised the labor participation rates, hours, and earnings of those who were eligible to receive it.

\section{INTRODUCTION}

$\mathrm{D}$ uring recent years, earned income tax credits (EITCs) have been introduced or expanded in many developed nations. EITCs generally have three goals: to boost labor supply, "make work pay," and improve the wellbeing of children. According to an international comparison by Banks, Disney, Duncan, and Van Reenen (2005), the largest EITC program is the UK tax credit, whose maximum benefit is one and a half times as large as the US EITC.

As well as being sizeable, the UK tax credit is also interesting because of its different structure. While the US, Belgian, Dutch and Finnish tax credits have a range in which the value of the credit increases with earnings, the UK tax credit (and the Irish EITC) becomes fully available at a certain threshold (Gradus, 2001). ${ }^{1}$ Without a "phase-in" range, theory predicts that the effect of the UK tax credit on labor force participation for singles should be unambiguously positive, the effect on labor force participation for secondary earners should be unambiguously negative, and the effect on hours for those already in the labor force and earning over the threshold should be unambiguously negative.

This paper considers the impact of the UK tax credit on labor supply and earnings, exploiting a 1999 increase in the

1 The UK credit is also boosted by a small amount if the recipient works 30 hours or more. 
credit as a natural experiment. In contrast to most research on tax credits, which have used cross-sectional data, I make use of a fifteen-month panel dataset, making it possible to hold constant individual-specific factors and identify the policy impact by comparing changes in the treatment group with changes in the control group.

To presage my results, I find that the 1999 increase in the UK tax credit boosted the labor force participation, hours and earnings of workers who were eligible for the tax credit. These results are robust to a range of different treatment and control groups, and do not appear to be driven by other policy changes that occurred in 1999 and 2000.

The remainder of this paper is organized as follows. The second section provides some background on the UK tax credit and briefly discusses the relevant literature. The third section presents the empirical strategy and results. The fourth section provides robustness checks, and the final section discusses the results and concludes.

\section{EARNED INCOME TAX CREDITS IN THE UNITED KINGDOM}

Since 1971, Britain has had some form of means-tested benefit for adults with children who worked more than a certain number of hours per week (Dilnot and McCrae, 1999). This has variously been known as the Family Income Supplement (1971-88), the Family Credit (1988-99), the Working Families Tax Credit (1999-2003) and, most recently, the Working Tax Credit. Due to the ever-changing nomenclature of the program, this paper will simply refer to it as the "UK tax credit." I begin by describing the basic parameters of the UK tax credit, before moving to describe the 1999 reform that is the focus of this paper.
During the time period covered by this study, a family needed to meet four requirements to be eligible for the UK tax credit. The family must have had: (a) at least one adult who is working 16 hours or more per week; (b) at least one dependent child (aged under 16, or aged 16-18 and in full-time education); (c) fungible assets below $£ 8000$; and (d) income below the phaseout point. If a family met these conditions, the credit amount depended on the age and number of eligible children, and the family's income. For family incomes below a specified threshold ( $£ 80.65$ per week before the reform, $£ 90$ afterwards), the full credit was paid. Beyond this point, the credit tapered off with additional earnings (at a rate of 70 percent before the reform, 55 percent afterwards). The UK tax system operates on an individual basis, but married or de facto couples claiming the credit must apply together, based on their joint circumstances.

The UK tax credit differs from the US EITC in five major respects. First, the UK credit has no phase-in range. The credit is unavailable to those working below 16 hours, and fully available to those working 16 hours or more, with a small additional credit amount available to those who work 30 hours or more. Second, the phaseout range is substantially steeper (the effective marginal tax rates in the phaseout range after the 1999 reform was at least 55 percent, higher than the top marginal tax rate in the UK at the time). Third, while the US has made a small EITC payment available to childless workers since 1994, UK tax credits were only extended to those without children in 2003. ${ }^{2}$ In the years that this paper focuses on, UK tax credits were unavailable to childless adults; furthermore, the UK tax credit system also provided a generous childcare tax credit. Fourth, while over 99 percent of US EITC recipients obtain their credit at the end of the tax year (US Trea-

2 For more detail on the 2003 tax credit reforms, see Brewer (2003). 
sury, 2003), UK recipients chiefly obtain the credit through their pay packet, with the amount based on their earnings over the previous three months. Indeed, since April 2000 many recipients-and most lone parents-have been paid the credit in this manner. ${ }^{3}$ And fifth, the levels of income support in the UK are similar to the value of the tax credit. ${ }^{4}$ For example, after the October 1999 reforms, a single woman with two children aged under 11 would have been entitled to income support of $£ 101.20$ per week if she worked less than 16 hours per week; or a tax credit of $£ 92.00$ if she worked 16 hours or more, but earned below $£ 90$ (working would also entitle her to a 70 percent rebate on childcare costs). Moreover, in the case of those with young children, income support was also increased by a similar amount to the tax credit in October 1999, making it likely that any estimates in this paper will be an underestimate of what would have occurred if the tax credit were increased, but welfare remained constant. ${ }^{5}$

Figure 1 shows how the budget constraint is affected by the UK tax credit and the US EITC. The graph is constructed based on the UK tax credit after the 1999 reform and the US EITC parameters in 1999. It assumes a single worker with two children under 11, earning US\$10 per hour,

Figure 1. Budget Constraint Under the US and UK Tax Credits

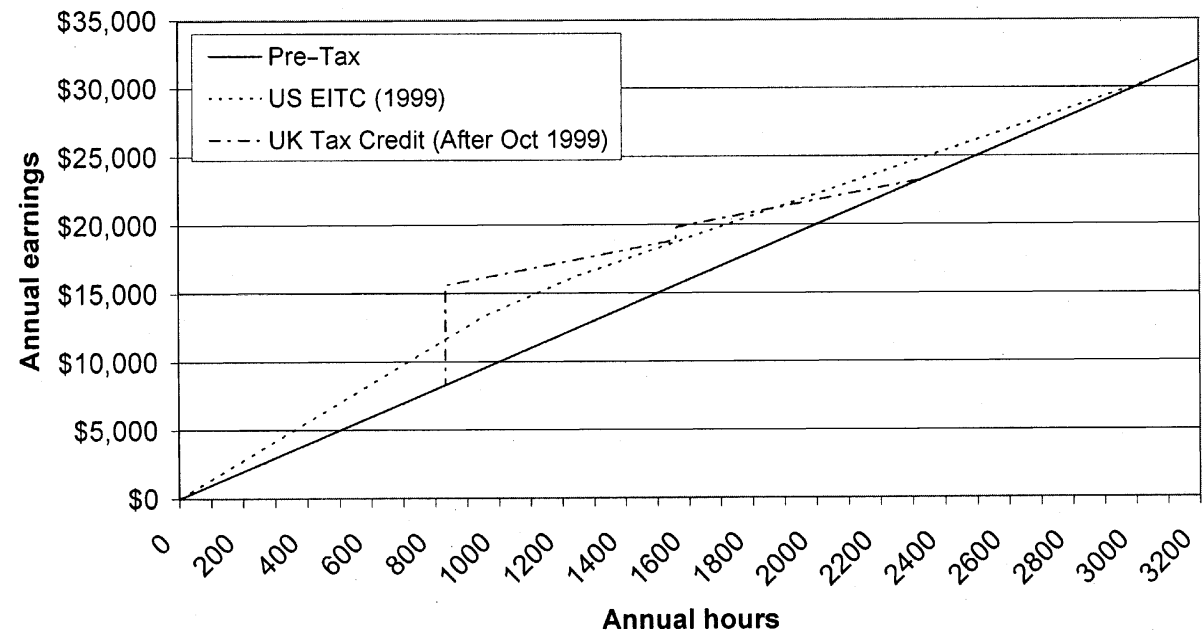

Note:Assumes a single taxpayer with two children aged under 11 and no investment income, earning US\$10 per hour or $£ 6.20$ per hour. Ignores other taxes and National Insurance Contribution.

\footnotetext{
3 Since April 2000, the only exceptions to the rule that the credit must be paid through the employee's pay packet are for applicants who are not employed (the credit continues to be paid out for some time after termination of employment), for the self-employed, and in situations where the non-working partner in a couple claimed the credit. The latter is the most important exception, since the majority of couples had the credit paid to the non-working partner. See http://www.inlandrevenue.gov.uk/manuals/acgmanual/Introduction/acg00020. htm.

4 Lone parents caring for a child aged under 16 are eligible for income support if they meet the income and assets tests, and are not working more than 16 hours per week. Married couples or de facto married couples are eligible for jobseeker benefits if they are unemployed and actively seeking work.

5 The income support allowance for those with children aged under 11 was increased by $£ 5.10$ per week. Income support payments for parents with older children were unaffected.
} 
which was then equivalent to $£ 6.20 .^{6}$ The jagged piece of the budget constraint for the British tax credit reflects the fact that, although low-wage employees get a basic tax credit at 16 hours and an additional amount at 30 hours; the 16-hour credit has already begun to phase out before the 30-hour credit becomes available. For many recipients, the UK tax credit does not have a flat region. In the stylized example in Figure 1, there is no flat region, since 16 hours at $£ 6.20$ per hour equates to weekly earnings of $£ 99.20$, which is already in the phaseout range. Where individuals face a flat region, it typically only covers a short range of hours (even after the October 1999 increase, a single mother on the minimum wage would be in the phaseout range if she worked more than 25 hours per week). Overall, the UK tax credit is more targeted than the US EITC, but has an immediate phase-in, only a short flat area, and a rapid phaseout. ${ }^{7}$

The change that this paper will focus upon is a significant credit increase, which took place on October 5, 1999. The new tax credit was more generous than its predecessor in five main respects (Blundell, Duncan, McCrae, and Meghir, 2000): ${ }^{8}$

- it increased the basic credit from $£ 48.80$ to $£ 52.30$ per week;
- it increased the per-child credit for children under 11 from $£ 14.85$ to $£ 19.85$ per week;

- it increased the threshold before earnings began to taper off from $£ 80.65$ to $£ 90$ per week;

- it reduced the taper rate from 70 percent to 55 percent; ${ }^{9}$ and

- it included a childcare credit of 70 percent of actual childcare costs up to $£ 150$ per week. ${ }^{10}$

The effect of these changes on the budget constraint is shown in Figure 2, which uses the same parameters as Figure 1. Note that both charts assume that the worker does not take advantage of the childcare tax credit. Under the old credit, this particular worker was eligible for the tax credit only if she earned less than $£ 208$ per week. Under the new credit, the worker remained eligible with earnings of up to $£ 277$ per week.

Additionally, at the same time as Britain increased the tax credit, it also boosted out-of-work benefits for families with one or more children aged under 11 . Since the timing was coincident with the increase in the tax credit, this paper will not attempt to disentangle the two reforms. However, it is worth noting that the labor force participation effect that

6 Exchange rate calculation from http://www.oanda.com/convert/fxhistory.

7 Even after the April 2003 reforms to the UK tax credit, the phaseout rate is 37 percent, considerably higher than the phaseout rates for the US EITC (7.65 percent for workers without children, 15.98 percent for workers with one child, and 21.06 percent for workers with two or more children).

8 The October 1999 reform also shifted the administration of the tax credit from the Benefits Agency to Inland Revenue.

9 The taper rate for the UK tax credit applied to earnings after income tax and payroll tax (known in the UK as the national insurance contribution) had been deducted. For a worker in the phaseout range whose annual earnings were below the lower earnings limit for both payroll and income taxes $(£ 3,432$ per year in $1999-2000)$ the effective marginal tax rate was simply the taper rate (70 percent before October 5, 1999, 55 percent thereafter). For this worker, the reduction in the effective marginal tax rate would simply have been 15 percent (70 percent -55 percent). But for a worker in the phaseout range who was subject to the ten percent payroll tax and income taxes, the effective marginal tax rate in 1999-2000 would have been $\{(0.1+$ income tax rate $)$ $+(1-0.1-\text { income tax rate })^{*}$ taper rate . Where these other taxes applied, the reduction in the effective marginal tax rate arising from the 15 percent reduction in the taper rate would have been somewhat less than 15 percent. For example, if the individual's marginal income tax rate was ten percent, the reduction would have been 12 percent ( 76 percent -64 percent).

10 Prior to this, a portion of childcare costs was "disregarded" from income used to calculate eligibility for the tax credit. 
Figure 2. Budget Constraint Before and After the October 1999 Reform

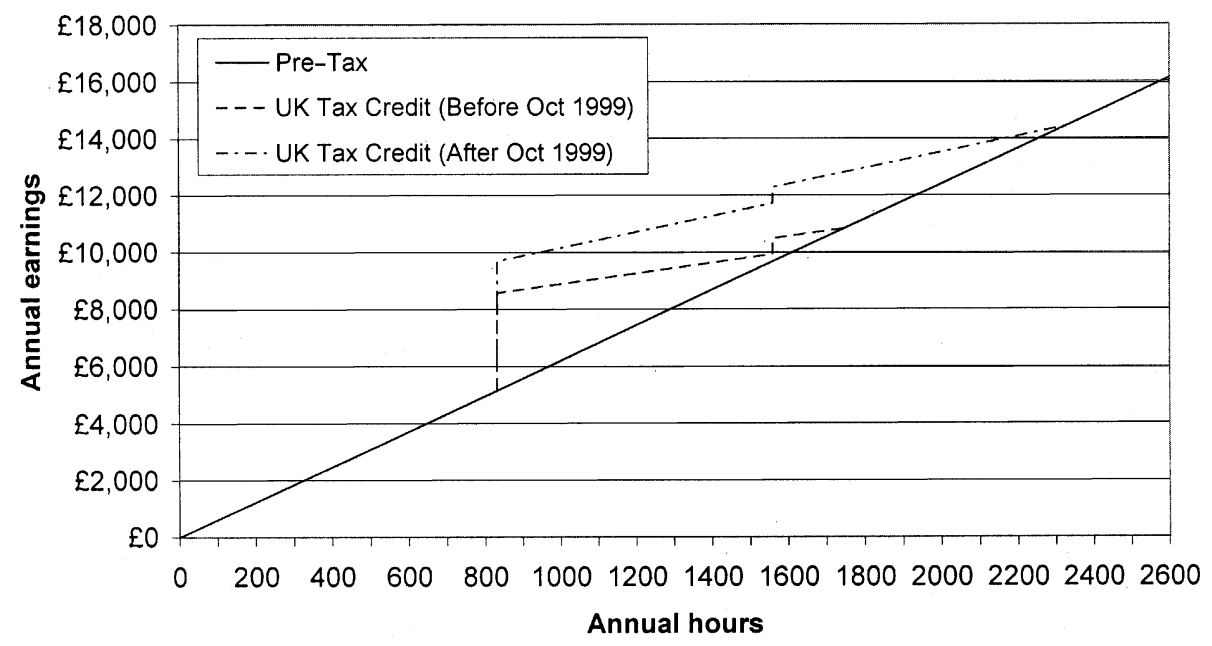

Note: Assumes a single taxpayer with two children aged under 11 and no investment income, earning £6.20 per hour. Ignores other taxes and National Insurance Contribution.

might be expected to occur from boosting in-work benefits alone is larger than the labor force participation effect one might expect given an increase in both in-work and out-of-work benefits.

As administrative data show, the October 1999 changes prompted a substantial increase in the number of tax credit recipients and the average credit amount (Inland Revenue, 2003). These data are plotted in Figure 3, which depicts the number of tax credit recipients, and Figure 4, which shows the average credit amount. Over the 15-month period from March 1999 to May 2000, the number of tax credit recipients rose by 29 percent (from 821,300 to $1,061,400)$, while the average credit amount rose by 16 percent (from $£ 62.99$ per week to $£ 73.28$ ). However, while there was no discernible increase in takeup between the announcement of the credit increase in the March 1998 budget statement and its implementation in October 1999, we cannot conclusively reject an anticipation effect, since the March 1998 announcement might nonetheless have had some impact on labor supply.
What effect does theory suggest that the 1999 changes to the British tax credit and child credits should have had on labor supply? The most straightforward case is that of low-income single parents. For those who were working too few hours to be eligible (i.e., not working or working less than 16 hours per week), we should have expected an increase in labor supply. For eligibles in the flat region, we should have expected a fall in hours, since the policy change increased their income without affecting their marginal tax rate. For those in the phaseout region, the expected effect is ambiguous, since the policy change decreased their effective marginal tax rate, but increased their income. For couples, the expected effect of the policy changes depended upon the earnings and hours of both members.

Evidence from the US EITC suggests that increasing the generosity of the program can have a large impact on labor supply, particularly on the participation margin. Eissa and Liebman (1996) use a differences-in-differences approach to analyze the 1987 increase in the US EITC, 
Figure 3. Number of Tax Credit Claimants ('000s)

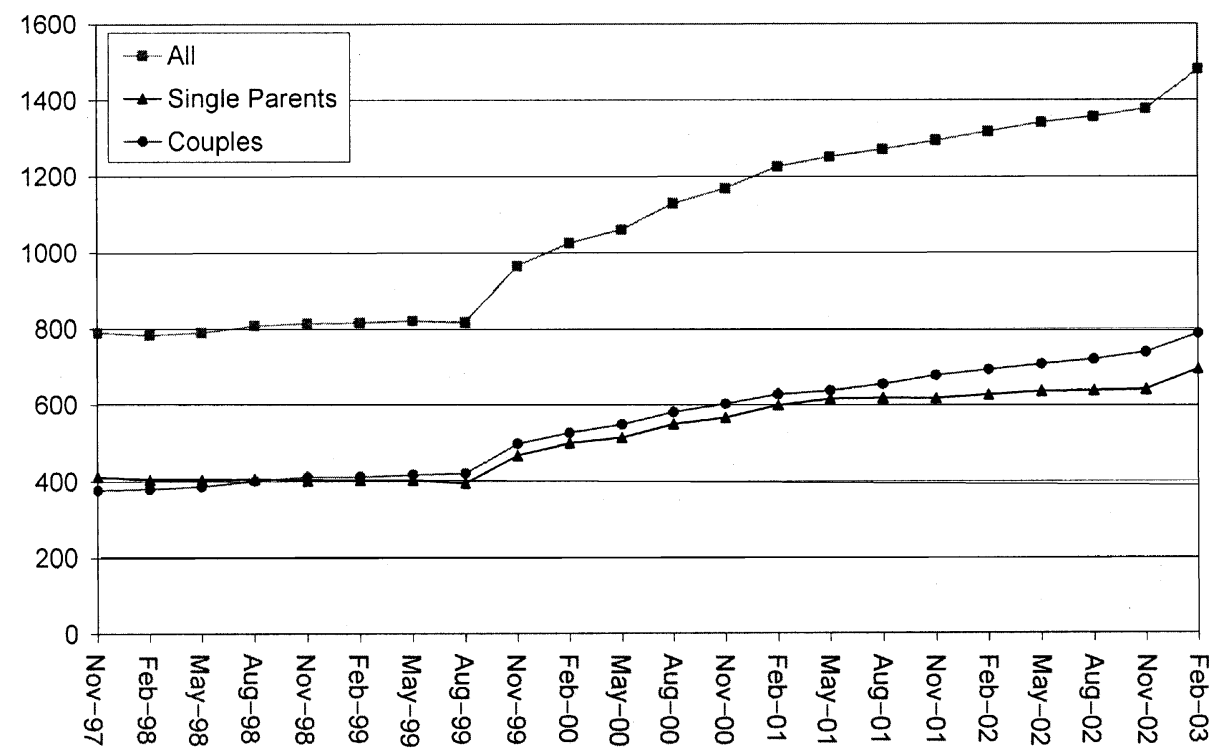

Figure 4. Average Weekly Tax Credit Amount

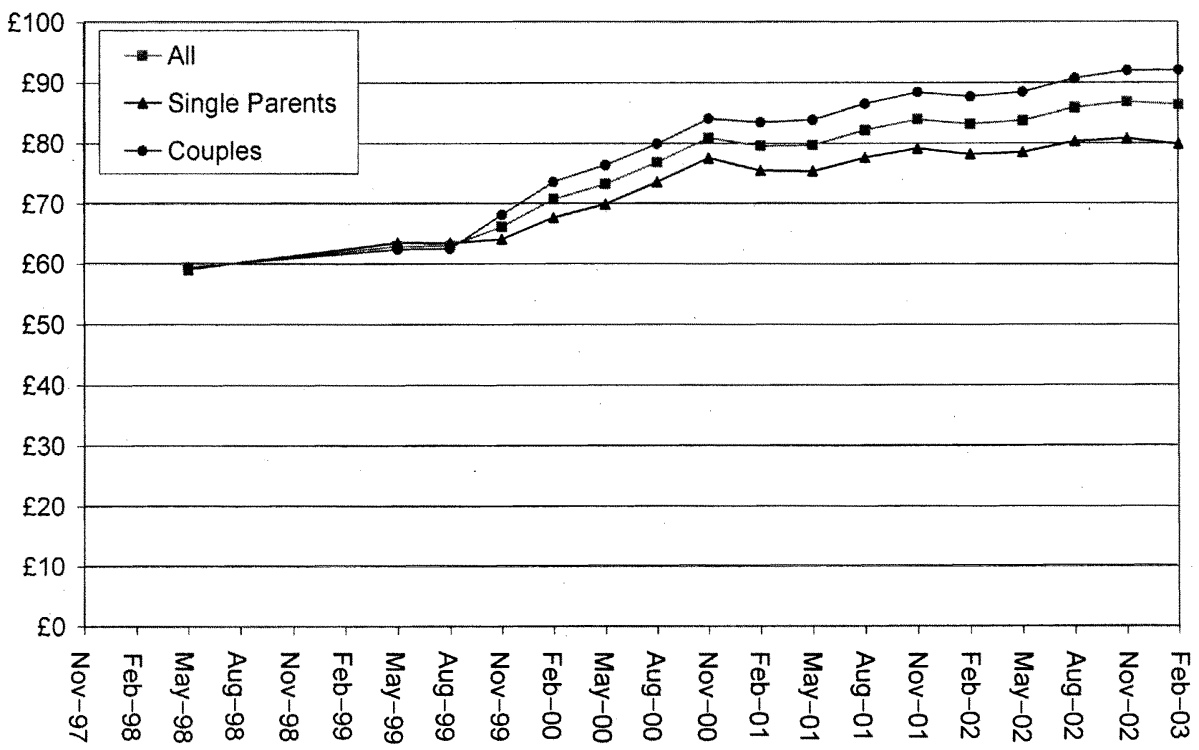


and find that it led to a 2.8 percentage point increase in the relative participation rates of single women with children, but had no effect on the hours of those already in the labor force. Meyer (2002) charts changes in labor force participation over the period 1986-2000, and concludes similarly that the credit boosted labor supply on the participation margin, but had no significant effect on the hours margins for low-wage workers. Meyer looks at a variety of demographic groups, but concludes that the EITC primarily affected single women. Exploring whether this effect was due to the EITC or to welfare reform, Meyer and Rosenbaum (2001) model the impact of both tax and welfare changes, and conclude that most of the increase in labor force participation was due to tax changes.

Several US studies suggest that the EITC may lower labor force participation for secondary earners in circumstances where one adult is already working. This could be due either to the income effect (which would apply to all recipient households) or to the substitution effect (which would apply to households in the phaseout range). Analyzing the negative income tax experiments of the 1970s, Hausman (1985) concludes the income effect was significant and could lead to a decrease in labor supply. Comparing labor force participation of low-skill and high-skill married women, Ellwood (2000) finds that EITC expansions over the period 1986-99 reduced the labor supply of married women in EITC-eligible families by between three and seven percentage points. And comparing low-skill married couples with children to low-skill childless couples over the period 1984-96, Eissa and Hoynes (2004) conclude that boosting the EITC reduced wives' labor supply by one percentage point, which they attribute primarily to the income effect.

What is the effect on total earnings of raising the EITC? Using variation across states and occupational groups, Leigh (2004) finds that increases in the EITC are associated with a fall in pre-tax hourly wages for low-skilled workers, while using variation within skill groups, Rothstein (2006) finds that raising the EITC had no negative effect on hourly wages. If it is the case that wages fall when the EITC increases, then it is possible that an increase in labor supply does not fully flow through into increased earnings. However, two studies find that raising the EITC does, indeed, boost total earnings. Exploiting variation from US state EITCs, Neumark and Wascher (2001) find that states that introduce or increase an EITC raise the income-to-needs ratio for poor families. Similarly in Canada, Michalopoulos, Robins and Card (2005) study a randomly assigned EITC experiment, and conclude that the program had a strong positive effect on both employment and earnings. To account for the possibility that the UK tax credit might lower the equilibrium wage for low-skilled workers, it will be important to analyze its impact not only on labor supply, but also on earnings. ${ }^{11}$

Evidence on UK tax credits is more limited, but rapidly burgeoning. Using structural modeling, Blundell et al. (2000), Gregg, Johnson, and Reed (1999), and Paull, Walker, and Zhu (2000) predict that the 1999 reform should lead to a $1.5-2.5$ percentage point increase in the employment rate of single mothers, while Blundell et al. (2000) and Gregg et al. (1999) predict that the labor force participation rates for married women should fall (this is mostly due to the income effect:

\footnotetext{
11 Note that this is still an imperfect measurement of the effect of the policy change on earnings, since if workers eligible for the credit and workers ineligible for the credit work in the same occupations, then an EITC-induced increase in labor supply will drive down the hourly wage for both eligibles and ineligibles. In this instance, comparing the gross weekly earnings of eligibles and ineligibles might lead the researcher to overestimate of the impact of the policy on the welfare of eligibles (and ignore the detrimental effect on ineligibles).
} 
in households with a low-wage husband, an increase in family income decreases the probability that the wife will work). ${ }^{12}$ More recent work by Brewer, Duncan, Shephard, and Suárez (2003) uses data from the Family Resources Survey to simulate the effects of the changes that occurred between April 1999 and April 2000. They conclude that the total effect of these reforms was to boost the employment of single mothers by 3.4 percentage points, but reduce the employment of men and women in couples by 0.4 percentage points. Their simulations also indicate that the reforms should have increased the hours of working single mothers by 0.6 hours per week, increased the hours of married women by 0.3 hours per week, and reduced the hours of married men by 0.2 hours per week.

Two natural-experiment studies have focused on the effect that the suite of policy reforms implemented during the 1990s and early 2000s had on single mothers. Gregg and Harkness (2003) take single mothers as their treatment group and childless single women as their main control group. Using the UK Labour Force Survey (and the General Household Survey before that) as a repeated cross section, and with propensity score matching to balance the treatment and control groups on observable characteristics, they conclude that the policy reforms implemented over the period 1998-2002 boosted the employment rates of single parents by five percentage points, and increased average hours per week of those already in employment by 1.2 hours. In a study produced contemporaneously with the present study, Francesconi and van der Klaauw (2007) use the British Household Panel Survey and find that the reforms to the UK tax credit between 1991 and 2001 boosted the employment rates of single mothers by about five percentage points. On the question of incidence, Azmat (2006) finds that firms pay lower wages to those receiving the UK tax credit, and other unskilled coworkers.

This study presents a straightforward natural experiment, focusing on only the 1999 tax credit reform-the largest single increase in the UK tax credit. It differs from existing studies in that it focuses on a variety of treatment and control groups, and analyzes a broad range of outcomes, including labor force participation, the probability of working each number of hours from 1 to 50, and total earnings.

While the natural-experiment approach has the virtue of simplicity, it is important to recognize that in a reduced form evaluation such as this one, the presence of nonlinear budget sets and multiple changes to the structure of the tax credit will make it difficult to disentangle the precise effect of different parts of the tax credit schedule on employment, hours and earnings. This paper should, therefore, be regarded as an evaluation of the full set of changes that were made to the UK tax credit in 1999, rather than an attempt to separately identify the effects that different parts of the credit schedule might have on labor supply.

\section{EMPIRICAL STRATEGY AND RESULTS}

In order to analyze the impact of the UK tax credit, I use data from a special five-quarter longitudinal sample of the Quarterly Labour Force Survey (LFS). ${ }^{13}$ The LFS is a survey similar in nature to the US Current Population Survey, though with a somewhat smaller sample size. ${ }^{14}$ Each quarter, approximately 60,000

12 For a careful comparison of these three studies, see Blundell and Reed (2000).

13 The dataset is filed in the UK Data Archive as Study Number 4303 (2nd edition, May, 2003).

14 The sample is further reduced for earnings questions, since these are asked in only Wave 1 and Wave 5, and in such a manner that the respondent has the opportunity to opt out of this part of the survey. Although this could potentially bias estimates of the impact of the October 1999 tax credit reform on earnings, the extent of this bias is limited through the inclusion of individual fixed effects. 
households are surveyed, comprising five waves of approximately 12,000 households. The waves are staggered, so that from one quarter to the next, one wave drops out, and another enters. The longitudinal sample covers a single wave of respondents over five quarters.

A strategy akin to differences-indifferences is employed, comparing outcomes in the two quarterly surveys before the change (March to August 1999) with outcomes in the two quarterly surveys after the change (December to May 2000). However, unlike a standard differencesin-differences approach, I take advantage of the panel structure of the data to include an individual fixed-effect term, so the results are identified only from changes in individuals' behavior, not from shifts in the composition of the sample. Since the tax credit increase occurred in October 1999, the survey conducted from September to November 1999 is omitted from the analysis. All respondents in the five-quarter longitudinal dataset were first observed in the March 1999 quarter. In total, 98.9 percent also answered the survey in the last quarter (May 2000), and 96.7 percent answered the survey in all four of the quarters used in this study (March 1999, August 1999, December 1999, and May 2000). Non-response bias is addressed through the use of longitudinal weights (for more detail on the methodology used to create these weights, see Clarke and Tate (1999) and Office of National Statistics (2003)).

Five treatment-control pairings are identified:

- $\quad$ parents vs. childless adults;

- parents with predicted earnings below the median vs. childless adults with predicted earnings below the median;

- single mothers vs. single women without children; ${ }^{15}$

- non-single mothers vs. non-single women without children; and

- non-single fathers vs. non-single men without children.

In each case, the sample is restricted to prime age adults (those aged 25-59) who are not self-employed (this age range is selected since those aged over 59 are ineligible for the tax credit). Children are defined as dependent children aged under 16 , or aged 16-18 and in full-time education (the survey question corresponds to the eligibility requirements for the tax credit). Since tax credit rules treat married and de facto married couples in a similar manner, I group both together, rather than separating married and unmarried parents, as is more typical with US studies.

Table 1 presents summary statistics from Wave 1 for those without children (the control group in the first specification) and with children (treatment group). Those with children tend to be younger than their childless counterparts and tend to work slightly fewer hours (conditional on being employed), but the employment rates, gross weekly incomes and net weekly incomes of the two groups are otherwise quite similar. ${ }^{16}$

The basic regression model is to estimate the following equation:

$$
\begin{aligned}
& \text { [1] Outcome }{ }_{i t}=\alpha+\beta I_{i}^{\text {HasChildren }} \\
& { }^{*} I_{t}^{\text {AfterOctober } 1999}+\gamma I_{t}^{\text {After October } 1999} \\
& +\chi_{i}+\varepsilon_{i t},
\end{aligned}
$$

where the indicator variable $I^{\text {Has Children }}$ denotes that the individual has children in

\footnotetext{
15 Single fathers are not analyzed, since they comprise such a small slice of the population (just one-tenth of single parents living with dependent children in the UK are fathers).

16 A possible concern with using those without children as a control for those with children is if the tax credit itself changed the incentives to have children. However, this seems unlikely to be a problem. In the case of the US EITC, Baughman and Dickert-Conlin (2003) found that increasing the credit had no effect on the childbearing decisions of white women (and only a very small effect on childbearing decisions of non-white women).
} 
TABLE 1

SUMMARY STATISTICS-FULL SAMPLE

\begin{tabular}{|c|c|c|c|c|c|c|}
\hline & \multicolumn{3}{|c|}{ Without children (control) } & \multicolumn{3}{|c|}{ With children (treatment) } \\
\hline & Mean & SD & $\begin{array}{l}\text { Number of } \\
\text { individuals }\end{array}$ & Mean & $\mathrm{SD}$ & $\begin{array}{l}\text { Number of } \\
\text { individuals }\end{array}$ \\
\hline Male & 0.509 & 0.500 & 4,086 & 0.443 & 0.497 & 3,863 \\
\hline Age & 43.697 & 10.971 & 4,086 & 37.664 & 7.378 & 3,863 \\
\hline Black & 0.014 & 0.116 & 4,086 & 0.030 & 0.170 & 3,863 \\
\hline Asian & 0.018 & 0.132 & 4,086 & 0.038 & 0.191 & 3,863 \\
\hline Other non-white & 0.003 & 0.059 & 4,086 & 0.008 & 0.089 & 3,863 \\
\hline Education (years) & 11.486 & 1.974 & 4,086 & 11.444 & 1.954 & 3,863 \\
\hline Non-single & 0.660 & 0.474 & 4,086 & 0.850 & 0.357 & 3,863 \\
\hline No. of children & 0 & 0 & 4,086 & 1.866 & 0.902 & 3,863 \\
\hline Employed & 0.745 & 0.436 & 4,086 & 0.740 & 0.439 & 3,863 \\
\hline Weekly hours in all jobs & 35.480 & 16.353 & 3,008 & 33.261 & 17.462 & 2,923 \\
\hline Working $>16$ hours & 0.867 & 0.338 & 3,008 & 0.829 & 0.376 & 2,923 \\
\hline Working $>30$ hours & 0.743 & 0.436 & 3,008 & 0.647 & 0.477 & 2,923 \\
\hline Weekly earnings (pre-tax) & 350.519 & 227.374 & 2,454 & 340.122 & 266.817 & 2,485 \\
\hline Weekly earnings (post-tax) & 258.453 & 153.983 & 2,420 & 250.774 & 178.569 & 2,455 \\
\hline
\end{tabular}

wave one, $I^{\text {After October } 1999}$ denotes an observation after the policy came into effect, and $\chi_{i}$ is an individual-specific fixed effect. Since the indicator variable for having children is not allowed to change within a person, it is not necessary to include it separately, since it is absorbed in the person fixed effect. ${ }^{17}$ Standard errors are clustered at the person level, to take account of serial correlation across waves. "Outcome" is one of a variety of continuous and binary outcomes to be estimated.

I analyze six dependent variables. The first four are measures of labor supply: whether the respondent is employed, total weekly hours, whether the respondent works 16 hours or more, and whether the respondent works 30 hours or more (these last two are included to take account of the two thresholds in the tax credit schedule). The fifth and sixth dependent variables are log pre-tax earnings and log post-tax earnings.
In the case of continuous outcomes, I use a fixed effects ordinary least squares (OLS) specification. Where the outcome is binary, the two possible estimation methods are a fixed effects logit model, and a fixed effects OLS model (since fixed effects probit and tobit are both known to be biased). I opt here for the latter, though the results are not qualitatively different when the former is used instead. Note that since this is a person fixed effects specification, the impact of the reform on hours and earnings is estimated only for those who were in the workforce both before and after October 1999. ${ }^{18}$ Appendix 1 compares the results from this fixed effects specification with two alternative models-a simple differences-in-differences estimator, and a matched differences-in-differences estimator-and finds similar results for the outcomes of hours worked and gross income.

17 A small number of respondents changed eligibility status between the before and after period. One and seven-tenths percent were ineligible for one or both of the before quarters, but eligible for one or both of the after quarters. Two and eight-tenths percent were eligible for one or both of the before quarters, but ineligible for one or both of the after quarters. To take account of this, I code individuals according to whether they were in the control or treatment group in the first quarter. Alternatively, one might include both a "has dependent children" variable and individual fixed effects. Doing so makes no substantive difference to the results.

18 Since the individual fixed effects specifications are identified off those who change status, it is useful to summarize the fraction of all respondents for whom the dependent variable changed in at least one of the four quarters: employment-12 percent, hours-69 percent, $>16$ hours-ten percent, $>30$ hours-17 percent, pre-tax earnings -49 percent, post-tax earnings -48 percent. 
Table 2 presents the results from the first regression specification, using all parents as the treatment group and adults without children as the control group. Making the tax credit more generous appears to have led to a one percentage point rise in the relative employment rate of those in the treatment group, a 1.3 hour rise in average weekly hours, a 2.5 percentage point relative rise in the probability that those in the treatment group would work 16 hours or more per week, and a 3.1 percentage point relative rise in the probability of working 30 hours or more per week. Relative to the control group, gross earnings rose by 4.6 percent, and net earnings, by 3.3 percent.

In Table 2, the only hours of work specifications tested are the probability of working 16 hours or more and the probability of working 30 hours or more. To gain a fuller picture across the hours distribution, I test the effect of the reform on the probability of working each number of hours from 1 to 50. Unlike Table 2, I now code those who do not work as having zero hours. The results of this specification are shown in Figure 5, along with dashed lines denoting the 90 percent confidence interval for the estimates. This suggests that the 1999 reform had a positive effect on hours worked at all points in the hours distribution. Interestingly, significant hours effects are observed for the higher part of the distribution (even up to 40 hours per week), above the point at which the 30-hour tax credit becomes available. Indeed, I find no evidence of bunching in the estimated policy effect at either the 16-hour threshold or the 30-hour threshold. This would be consistent with a model in which workers have control over their labor force participation, but not over their precise weekly hours.

Next, I confine the sample to those most likely to be affected by the reform. Choosing only those with low earnings would be to select on the dependent variable. So instead, I first run a regression of log weekly earnings in the March 1999 quarter (prior to the tax credit reform) on a set of demographic characteristics that would not have been affected by the reform: sex, age, age ${ }^{2}$, race dummies, education dummies, plus interactions between education and age, and between education and sex. Using this, I then predict each person's earnings and restrict the sample to those whose earnings are in the lower half of the predicted earnings distribution.

TABLE 2

FULL SAMPLE

Treatment group: Parents

Control group: Childless adults

\begin{tabular}{|c|c|c|c|c|c|c|}
\hline & $\begin{array}{c}(1) \\
\text { Employed }\end{array}$ & $\begin{array}{c}(2) \\
\text { Total weekly hours }\end{array}$ & $\begin{array}{c}(3) \\
>16 \text { hours }\end{array}$ & $\begin{array}{c}(4) \\
>30 \text { hours }\end{array}$ & $\begin{array}{c}(5) \\
\text { Log } \\
\text { (pre-tax } \\
\text { earnings) }\end{array}$ & $\begin{array}{c}(6) \\
\text { Log } \\
\text { (post-tax } \\
\text { earnings) }\end{array}$ \\
\hline Treat*After & $\begin{array}{c}0.009^{*} \\
{[0.005]}\end{array}$ & $\begin{array}{c}1.284^{* * *} \\
{[0.387]}\end{array}$ & $\begin{array}{c}0.025^{* * *} \\
{[0.009]}\end{array}$ & $\begin{array}{c}0.031^{* * *} \\
{[0.010]}\end{array}$ & $\begin{array}{c}0.046^{* * *} \\
{[0.012]}\end{array}$ & $\begin{array}{c}0.033^{* * *} \\
{[0.011]}\end{array}$ \\
\hline After & $\begin{array}{c}-0.008^{* *} \\
{[0.003]}\end{array}$ & $\begin{array}{c}-1.266^{* * *} \\
{[0.270]}\end{array}$ & $\begin{array}{c}-0.008 \\
{[0.006]}\end{array}$ & $\begin{array}{c}-0.028^{* * *} \\
{[0.007]}\end{array}$ & $\begin{array}{c}0.004 \\
{[0.009]}\end{array}$ & $\begin{array}{c}0.01 \\
{[0.007]}\end{array}$ \\
\hline $\begin{array}{l}\text { Indiv. FE? } \\
N \\
\mathrm{R}^{2}\end{array}$ & $\begin{array}{c}\text { Yes } \\
31,391 \\
0.90\end{array}$ & $\begin{array}{c}\text { Yes } \\
23,625 \\
0.57\end{array}$ & $\begin{array}{c}\text { Yes } \\
23,625 \\
0.69\end{array}$ & $\begin{array}{c}\text { Yes } \\
23,625 \\
0.74\end{array}$ & $\begin{array}{c}\text { Yes } \\
10,192 \\
0.95\end{array}$ & $\begin{array}{c}\text { Yes } \\
10,084 \\
0.95\end{array}$ \\
\hline
\end{tabular}

Note: ${ }^{* * *},{ }^{* *}$ and ${ }^{*}$ denote significance at the $1 \%, 5 \%$ and $10 \%$ levels, respectively. Robust standard errors, clustered at the individual level, are in parentheses. Specifications including work hours are restricted to those in employment. Earnings are combined weekly earnings from main job and any secondary job. Post-tax earnings take into account income taxes and tax credits. "Treat" denotes individuals in the treatment group, while "After" denotes observations after October 1999. 
Figure 5. Employment Participation Gap Between Treatment and Control Groups, for Various Numbers of Hours

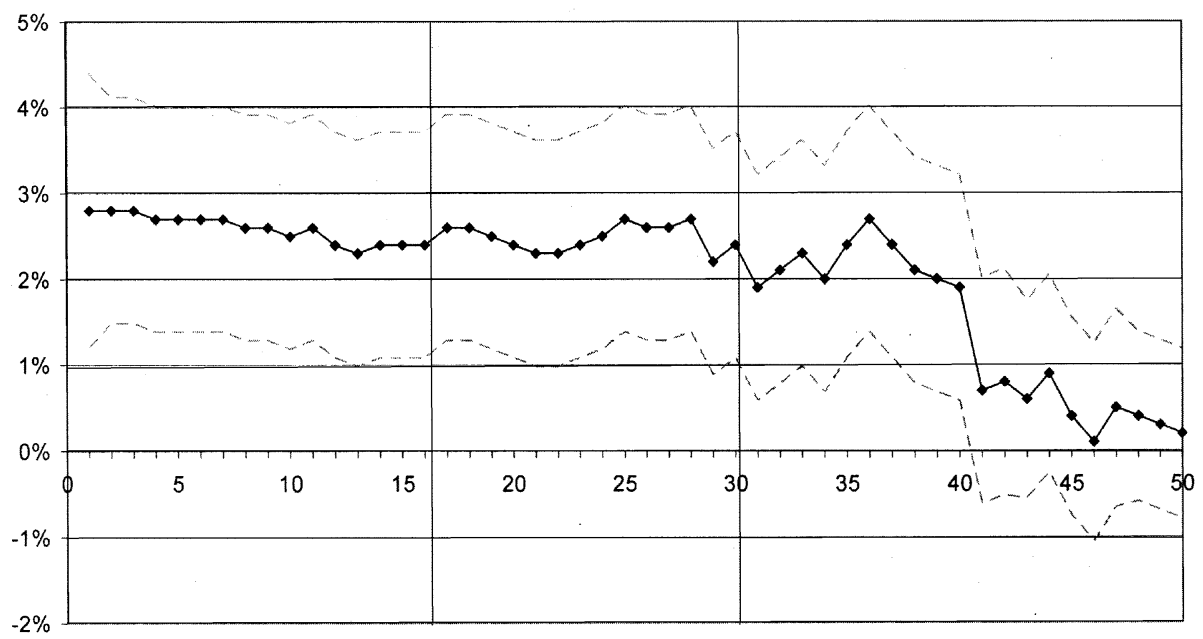

Note: Estimates show the effect of the tax credit reform on the probability that the individual will work a given number of hours or more.

Table 3 presents summary statistics for the predicted poor without children (control group for this specification) and with children (treatment group), as measured in Wave 1. Those with children tend to be younger than their childless counterparts, less likely to be in employment (by a margin of seven percentage points), likely to work fewer hours (conditional on being employed), and tend to have lower gross and net weekly earnings. On gender and education, the two groups are quite similar. Overall, while the two groups are reasonably alike, the gap in labor market outcomes between the treatment and control groups is more sizeable for the predicted poor than it was for the full sample.

Table 4 shows the results of estimating equation [1], but with the sample restricted

TABLE 3

SUMMARY STATISTICS-PREDICTED POOR

\begin{tabular}{|c|c|c|c|c|c|c|}
\hline & \multicolumn{3}{|c|}{ Without children (control) } & \multicolumn{3}{|c|}{ With children (treatment) } \\
\hline & Mean & SD & $\begin{array}{l}\text { Number of } \\
\text { individuals }\end{array}$ & Mean & SD & $\begin{array}{l}\text { Number of } \\
\text { individuals }\end{array}$ \\
\hline Male & 0.106 & 0.308 & 2,036 & 0.096 & 0.295 & 2,000 \\
\hline Age & 44.356 & 11.326 & 2,036 & 35.676 & 7.176 & 2,000 \\
\hline Black & 0.012 & 0.110 & 2,036 & 0.037 & 0.189 & 2,000 \\
\hline Asian & 0.021 & 0.144 & 2,036 & 0.049 & 0.215 & 2,000 \\
\hline Other non-white & 0.004 & 0.061 & 2,036 & 0.008 & 0.089 & 2,000 \\
\hline Education (years) & 10.628 & 1.395 & 2,036 & 10.517 & 1.181 & 2,000 \\
\hline Non-single & 0.682 & 0.466 & 2,036 & 0.755 & 0.430 & 2,000 \\
\hline No. of children & 0 & 0 & 2,036 & 1.874 & 0.940 & 2,000 \\
\hline Employed & 0.697 & 0.460 & 2,036 & 0.622 & 0.485 & 2,000 \\
\hline Weekly hours in all jobs & 31.415 & 15.395 & 1,405 & 25.463 & 15.612 & 1,299 \\
\hline Working $>16$ hours & 0.833 & 0.372 & 1,405 & 0.734 & 0.441 & 1,299 \\
\hline Working $>30$ hours & 0.637 & 0.480 & 1,405 & 0.428 & 0.494 & 1,299 \\
\hline Weekly earnings (pre-tax) & 244.578 & 153.193 & 1,141 & 197.533 & 161.133 & 1,125 \\
\hline Weekly earnings (post-tax) & 186.411 & 105.244 & 1,126 & 154.771 & 106.848 & 1,114 \\
\hline
\end{tabular}


TABLE 4

PREDICTED POOR

Treatment group: Parents with predicted earnings below the median Control group: Childless adults with predicted earnings below the median

\begin{tabular}{|c|c|c|c|c|c|c|}
\hline & $\begin{array}{c}(1) \\
\text { Employed }\end{array}$ & $\begin{array}{c}(2) \\
\text { Total weekly hours }\end{array}$ & $\begin{array}{c}(3) \\
>16 \text { hours }\end{array}$ & $\begin{array}{c}(4) \\
>30 \text { hours }\end{array}$ & $\begin{array}{c}(5) \\
\text { Log } \\
\text { (pre-tax } \\
\text { earnings) }\end{array}$ & $\begin{array}{c}(6) \\
\text { Log } \\
\text { (post-tax } \\
\text { earnings) }\end{array}$ \\
\hline Treat*After & $\begin{array}{c}0.014^{*} \\
{[0.008]}\end{array}$ & $\begin{array}{c}1.572^{* * *} \\
{[0.512]}\end{array}$ & $\begin{array}{l}0.032^{* *} \\
{[0.015]}\end{array}$ & $\begin{array}{c}0.023 \\
{[0.015]}\end{array}$ & $\begin{array}{c}0.056^{* * *} \\
{[0.018]}\end{array}$ & $\begin{array}{c}0.064^{* * *} \\
{[0.017]}\end{array}$ \\
\hline After & $\begin{array}{c}-0.011^{* *} \\
{[0.005]}\end{array}$ & $\begin{array}{c}-1.112^{* * *} \\
{[0.369]}\end{array}$ & $\begin{array}{c}-0.004 \\
{[0.010]}\end{array}$ & $\begin{array}{c}-0.019 * \\
{[0.010]}\end{array}$ & $\begin{array}{c}-0.003 \\
{[0.011]}\end{array}$ & $\begin{array}{c}-0.003 \\
{[0.010]}\end{array}$ \\
\hline Indiv. FE? & Yes & Yes & Yes & Yes & Yes & Yes \\
\hline $\mathrm{N}$ & 16,018 & 10,827 & 10,827 & 10,827 & 4,720 & 4,672 \\
\hline $\mathrm{R}^{2}$ & 0.9 & 0.62 & 0.72 & 0.77 & 0.95 & 0.95 \\
\hline
\end{tabular}

Note: ${ }^{* * *},{ }^{* *}$ and $*$ denote significance at the $1 \%, 5 \%$ and $10 \%$ levels, respectively. Robust standard errors, clustered at the individual level, are in parentheses. Specifications including work hours are restricted to those in employment. Earnings are combined weekly earnings from main job and any secondary job. Post-tax earnings take into account income taxes and tax credits. "Treat" denotes individuals in the treatment group, while "After" denotes observations after October 1999. Sample is restricted to those whose predicted individual earnings in Wave 1 (based on a regression of earnings on sex, age, age ${ }^{2}$, race dummies, education dummies, interactions between education and age, and interactions between education and sex) are below the median in the sample ( $£ 245$ per week).

to the predicted poor. Among those whose demographic characteristics predict that they will have below-average earnings, the 1999 tax credit reform boosted relative employment rates, hours, and earnings for the treatment group. In general, the coefficients are larger in magnitude for the predicted poor than for the full sample, but less precisely estimated.

Table 5 shows results for the last three specifications - single women, non-single women, and non-single men. While the standard errors are higher-in some cases making them statistically indistinguishable from zero- the point estimates are quite similar across the three groups. Together, these findings suggest that the 1999 reform boosted the employment probabilities, hours, and weekly earnings for single women, and for both partners within couples.

Can the positive impact of the reform on the labor force participation and hours of non-single women (Panel B) be reconciled with the findings of natural experiment-style studies on the US EITC (Ellwood, 2000; Eissa and Hoynes, 2004), and structural studies of the effect of the 1999 reforms to the UK tax credit (Brewer et al., 2003)? The most likely answer is that the reduction in the taper rate and the higher childcare tax credit had a sufficiently large positive effect on the hours of non-single women that it offset any negative effect on labor supply of increasing the maximum credit amount. ${ }^{19}$ In a context where secondary earners already face high marginal tax rates, it should not be surprising that a reform of this type can improve work incentives for partnered mothers as well as for single mothers. In the case of non-single men, the effects are mostly insignificant, with a positive effect on gross earnings, but not on net earnings, and a positive effect on the probability of working more than 30 hours that is only significant at the ten percent level. However, the results in Panel C do indicate that the reform did not reduce the labor force participation of non-single men.

\footnotetext{
19 Francesconi and van der Klaauw (2007, Fig 3B) find that the 1999 reforms were associated with an increase in lone mothers' usage of paid childcare.
} 
TABLE 5

DIFFERENT FAMILY TYPES

Panel A

Treatment group: Single mothers

Control group: Single women without children

\begin{tabular}{|c|c|c|c|c|c|c|}
\hline & $\begin{array}{c}(1) \\
\text { Employed }\end{array}$ & $\begin{array}{c}(2) \\
\text { Total weekly hours }\end{array}$ & $\begin{array}{c}(3) \\
>16 \text { hours }\end{array}$ & $\begin{array}{c}(4) \\
>30 \text { hours }\end{array}$ & $\begin{array}{c}(5) \\
\text { Log } \\
\text { (pre-tax } \\
\text { earnings) }\end{array}$ & $\begin{array}{c}\text { (6) } \\
\text { Log } \\
\text { (post-tax } \\
\text { earnings) }\end{array}$ \\
\hline Treat*After & $\begin{array}{c}0.006 \\
{[0.015]}\end{array}$ & $\begin{array}{c}1.731 \\
{[1.101]}\end{array}$ & $\begin{array}{c}0.002 \\
{[0.032]}\end{array}$ & $\begin{array}{c}0.043 \\
{[0.033]}\end{array}$ & $\begin{array}{c}0.022 \\
{[0.045]}\end{array}$ & $\begin{array}{c}0.049 \\
{[0.037]}\end{array}$ \\
\hline After & $\begin{array}{c}-0.01 \\
{[0.008]}\end{array}$ & $\begin{array}{c}-1.244^{*} \\
{[0.719]}\end{array}$ & $\begin{array}{c}0.011 \\
{[0.020]}\end{array}$ & $\begin{array}{l}-0.022 \\
{[0.021]}\end{array}$ & $\begin{array}{c}0.004 \\
{[0.017]}\end{array}$ & $\begin{array}{c}0.008 \\
{[0.015]}\end{array}$ \\
\hline $\begin{array}{l}\text { Indiv. FE? } \\
\mathrm{N} \\
\mathrm{R}^{2}\end{array}$ & $\begin{array}{c}\text { Yes } \\
4,223 \\
0.91\end{array}$ & $\begin{array}{c}\text { Yes } \\
2,669 \\
0.53\end{array}$ & $\begin{array}{c}\text { Yes } \\
2,669 \\
0.67\end{array}$ & $\begin{array}{c}\text { Yes } \\
2,669 \\
0.74\end{array}$ & $\begin{array}{c}\text { Yes } \\
1,163 \\
0.95\end{array}$ & $\begin{array}{c}\text { Yes } \\
1,157 \\
0.96\end{array}$ \\
\hline
\end{tabular}

Panel B

Treatment group: Non-single mothers

Control group: Non-single women without children

\begin{tabular}{|c|c|c|c|c|c|c|}
\hline Treat*After & $\begin{array}{l}0.016^{*} \\
{[0.008]}\end{array}$ & $\begin{array}{c}1.746^{* * *} \\
{[0.543]}\end{array}$ & $\begin{array}{c}0.045^{* * *} \\
{[0.017]}\end{array}$ & $\begin{array}{l}0.036^{* *} \\
{[0.016]}\end{array}$ & $\begin{array}{c}0.077^{* * *} \\
{[0.019]}\end{array}$ & $\begin{array}{c}0.075^{* * *} \\
{[0.017]}\end{array}$ \\
\hline After & $\begin{array}{c}-0.011^{* *} \\
{[0.006]}\end{array}$ & $\begin{array}{c}-0.890^{* *} \\
{[0.414]}\end{array}$ & $\begin{array}{c}-0.004 \\
{[0.012]}\end{array}$ & $\begin{array}{c}-0.025^{* *} \\
{[0.012]}\end{array}$ & $\begin{array}{c}-0.008 \\
{[0.015]}\end{array}$ & $\begin{array}{c}0 \\
{[0.012]}\end{array}$ \\
\hline Indiv. FE? & Yes & Yes & Yes & Yes & Yes & Yes \\
\hline $\mathrm{N}$ & 13,317 & 9,484 & 9,484 & 9,484 & 4,203 & 4,160 \\
\hline $\mathrm{R}^{2}$ & 0.89 & 0.59 & 0.71 & 0.77 & 0.95 & 0.95 \\
\hline
\end{tabular}

Panel C

Treatment group: Non-single fathers

Control group: Non-single men without children

\begin{tabular}{lcccccc}
\hline Treat ${ }^{*}$ After & 0.006 & 0.718 & 0.017 & $0.029^{*}$ & $0.046^{* *}$ & 0.01 \\
& {$[0.008]$} & {$[0.657]$} & {$[0.013]$} & {$[0.015]$} & {$[0.019]$} & {$[0.017]$} \\
& & & & & & \\
After & -0.01 & $-1.265^{* * *}$ & -0.014 & $-0.031^{* * *}$ & -0.003 & 0.009 \\
& {$[0.006]$} & {$[0.485]$} & {$[0.010]$} & {$[0.012]$} & {$[0.015]$} & {$[0.012]$} \\
& & & & & & Yes \\
Indiv. FE? & Yes & Yes & Yes & Yes & 4,040 & 3,987 \\
$\mathrm{~N}$ & 11,090 & 9,519 & 9,519 & 9,519 & 0.91 & 0.90 \\
$\mathrm{R}^{2}$ & 0.89 & 0.41 & 0.45 & 0.44 & Yes \\
\hline
\end{tabular}

Note: ${ }^{* *},{ }^{* *}$ and $*$ denote significance at the $1 \%, 5 \%$ and $10 \%$ levels, respectively. Robust standard errors, clustered at the individual level, are in parentheses. Specifications including work hours are restricted to those in employment. Earnings are combined weekly earnings from main job and any secondary job. Post-tax earnings take into account income taxes and tax credits. "Treat" denotes individuals in the treatment group, while "After" denotes observations after October 1999.

\section{ROBUSTNESS CHECKS}

Nineteen ninety-nine and 2000 were busy years for social policy reformers in the UK government. In addition to boosting the tax credit in October 1999, Britain introduced a national minimum wage on 13 April 1999, reduced the bottom tax rate on 6 April 2000, and made various changes to the National Insurance Con- tribution Scheme on 6 April 1999 and 6 April 2000. Might these have biased the results shown above?

One simple answer is to say that, given that both the treatment and control groups had similar weekly earnings at the outset, these other policy changes might have affected $\gamma$ (the coefficient on the "After October 1999" indicator variable), but 
should not have affected the coefficient of interest, $\beta$ (the coefficient on the interaction between the "After October 1999" indicator variable and the indicator variable for having children).

Another approach is to gauge the potential bias from studies focusing on these other reforms. In the case of the minimum wage, there is evidence to suggest that the bias was pretty insignificant. The group most likely to earn the minimum wage are young workers, and those aged under 25 were excluded from the foregoing regression results. ${ }^{20}$ Moreover, in an analysis of the effect of the minimum wage, Stewart (2004) looks at both adults and youths, and finds no adverse employment effects from its introduction. Focusing on lowwage workers in residential care homes, Machin and Wilson (2004) find a modest negative impact on employment.

A more parsimonious way of testing whether the results were affected by these policy reforms is to restrict the sample. Dickens and Manning (2002) find that virtually all the effects of the minimum wage increase had taken place within two months of its introduction. Therefore, by excluding surveys taken before the rise (March 1999), and in the subsequent two months (April and May 1999), I attempt to purge the results of any "minimum wage effect."

The tax and national insurance changes were more complex, but as with the minimum wage, it is difficult to see prima facie why they ought to have had a differential effect upon the treatment and control groups. Adam and Reed (2003) provide a detailed account of the national insurance changes, but the essence of the reforms is the following. In April 1999, the levels of weekly earnings at which employers start paying national insurance contributions were aligned with the weekly level of the income tax personal allowance, and a "kink" was removed from the employee and employer national insurance contribution schedule. ${ }^{21}$ In April 2000, the earnings threshold for employee national insurance contributions was increased slightly. The taxation changes involved the introduction of a ten percent tax rate in April 1999 (though this was unlikely to have affected those working sufficient hours to be eligible for the tax credit, it could nonetheless have induced an increase in labor supply among low-skill workers in the control group) and a reduction in the next lowest marginal tax rate from 23 percent to 22 percent in April 2000.

In the same manner as for the minimum wage, we can see whether the foregoing results were driven by the tax and national insurance changes by restricting the sample to a single tax year. Since survey responses from the 1998-99 tax year have already been removed from the sample, this merely involves excluding surveys taken after 6 April 2000. The restricted sample, purged of possible minimum wage, national insurance, and taxation effects, is a "before" period of June to August 1999, and an "after" period of December 1999 to 5 April 2000.22

Unfortunately, because earnings questions are only asked in the first and last quarters of the survey, we can no longer explore the effect of the tax credit changes on wages. In addition, because the results rely on within-person variation, removing some of the surveys restricts the number

\footnotetext{
20 In April 1999, the UK minimum wage was $£ 3.60$ per hour for workers aged 22 and over, and $£ 3.00$ per hour for workers aged 18-21. Since there was no minimum wage for workers aged under 18, almost all dependent children in the sample will have been unaffected by this change.

21 The kink point was at $£ 64$ per week in 1998-99, so while its abolition might have increased labor supply, it is unlikely to have interacted with the parameters of the UK tax credit.

22 However, it is important to note that if the minimum wage, national insurance, or income taxation changes caused significant anticipation effects or lagged effects, they might nonetheless still affect this restricted sample.
} 
TABLE 6

RESTRICTED SAMPLE

Treatment group: Adults with children

Control group: Adults without children

\begin{tabular}{lcccc}
\hline & $(1)$ & $(2)$ & $(3)$ & $(4)$ \\
& Employed & Total weekly hours & $>16$ hours & $>30$ hours \\
\hline Treat ${ }^{*}$ After & 0.005 & $1.438^{* * *}$ & $0.038^{* * *}$ & $0.042^{* * *}$ \\
& {$[0.005]$} & {$[0.540]$} & {$[0.013]$} & {$[0.013]$} \\
After & $-0.006^{*}$ & -0.008 & $0.020^{* *}$ & -0.009 \\
& {$[0.004]$} & {$[0.381]$} & {$[0.009]$} & {$[0.010]$} \\
Indiv. FE? & Yes & Yes & Yes & Yes \\
$\mathrm{N}$ & 18,743 & 14,160 & 14,160 & 14,160 \\
$\mathrm{R}^{2}$ & 0.93 & 0.63 & 0.75 & 0.81 \\
\hline
\end{tabular}

Note: ${ }^{* * *}, * *$ and ${ }^{*}$ denote significance at the $1 \%, 5 \%$ and $10 \%$ levels, respectively. Robust standard errors, clustered at the individual level, are in parentheses. "Treat" denotes individuals in the treatment group, while "After" denotes observations after October 1999. Sample is restricted to the period from June 1, 1999 to April 5, 2000.

of degrees of freedom in the model, which should, ceteris paribus, reduce the precision of the estimates.

Table 6 presents the results of this specification, for the first specification (comparing prime-age adults with children to prime-age adults without children). Here, the coefficient on being employed ceases to be significant (though remains positive), while the coefficients on total weekly hours, working 16 hours or more, and working 30 hours or more all remain positive and significant.

\section{DISCUSSION AND CONCLUSION}

Using a variety of treatment-control pairings, and relying only on withinindividual variation, the 1999 tax credit reforms appear to have had a positive impact on labor force participation and on hours worked. Comparing parents with childless adults, the policy led to a one percentage point boost in labor force participation, and a 1.1 hour increase in the working week for those already in the labor force. Hours increased across the distribution, with no evidence of bunching at the 16-hour and 30-hour thresholds. Across family types, the tax credit appeared to have increased hours worked for eligible single women, as well as for both men and women in couples.
The positive hours effect is robust to purging the sample of the possible effect of the UK minimum wage, tax changes, and national insurance contribution changes. The policy also boosted pre-tax earnings by five percent and post-tax earnings by three percent. Since there were around 12 million UK parents with dependent children in 2000, and given that annual expenditure on the UK tax credit rose by $£ 1.3$ billion in the period covered by this study, these results suggest that each additional entrant into the labor force cost the UK taxpayer around $£ 11,000$ per year, while each additional $£ 1$ in public expenditure on the UK tax credit boosted parents' pre-tax earnings by around $£ 7$.

How do these estimates compare to those in other papers to have evaluated the 1999 reforms? Recall that Brewer et al. (2003) estimated a structural model of individuals' preferences, and found that the October 1999 reform should have boosted the employment of single mothers by 3.4 percentage points, but reduced the employment of men and women in couples by 0.4 percentage points. By contrast, I find little evidence of heterogeneity across family types. Given the different data sources (Brewer et al. (2003) use the Family Resources Survey) and the fact that the present paper uses a natural experiment approach, it is probably not 
surprising that the results presented here differ somewhat.

In the case of single mothers, the results in this paper are also smaller than the two natural-experiment studies that focused on this group alone. Gregg and Harkness (2003) found that reforms to the tax credit brought about a five percentage point increase in single mothers' employment rates over the period 1998-2002, while Francesconi and van der Klaauw (2007) found that tax credit reforms over the period 1991-2001 led to a five percentage point increase in the labor force participation rate for single mothers, with most of the effect occurring in 1999. Although it is difficult to compare studies using different data sources and measuring effects over different time horizons, one possible way of reconciling the evidence is that part of the behavioral effect induced by the October 1999 reform took place outside the 15-month window covered by this study. ${ }^{23}$

What can the effects observed in this paper tell us about how the poor respond to changing economic incentives? One factor to note is that despite the fact that both welfare and the tax credit were boosted in October 1999, the reform nonetheless had a positive effect on labor supply. It is possible that this is due to the more generous childcare benefits available after the reform.

Another important feature to note about the 1999 tax credit increase is the finding that average hours for those already in the labor force increased. As Dilnot and McCrae (1999, p. 15) observed before the reform took effect, "[t]he apparently common-sense assumption that lowering tapers must be good is far from obviously true; it may be better to have higher taper rates affecting a smaller group." My results show that the combined effect of a lower taper rate and a more generous maximum credit was to boost hours for those already in employment. Since theory unambiguously predicts that a more generous maximum credit amount should reduce hours for those in employment, it seems likely that the increase in hours can be ascribed to the lower taper rate. This suggests that lowering the taper rate did, indeed, boost hours for those already in employment, despite the fact that more people now found themselves in the phaseout range. For those designing tax credits in other countries, lower phaseout rates do appear to have a positive impact on labor supply.

Lastly, a more general point is in order. The UK tax credit is different in many respects to the US EITC. Yet both appear to have had a positive impact on labor supply. Carefully designing tax credit programs is important, but it is useful to see that positive employment effects can flow from programs that are structurally quite different from one another.

\section{Acknowledgments}

I am grateful to Christopher Jencks, Lawrence Katz, Jeffrey Liebman, participants at the Australasian Labour Econometrics Workshop and a Harvard University seminar, and two anonymous referees for helpful comments and suggestions on an earlier draft.

\section{REFERENCES}

Adam, Stuart, and Howard Reed.

"Income Tax and National Insurance Contributions." In The IFS Green Budget edited by Robert Chote, Carl Emmerson, and Helen Simpson, 54-63. London: Institute for Fiscal Studies, 2003.

\footnotetext{
${ }_{23}$ Some evidence from this can be seen simply from looking at the takeup rates in Figure 3 . With the boost in the value of the UK tax credit during the 1999-2000 tax year, the number of claimants rose by 29 percent. In the 2000-01 tax year, the parameters of the credit remained basically unchanged, yet the number of claimants rose by a further 17 percent.
} 
Azmat, Ghazala.

"The Incidence of an Earned Income Tax Credit: Evaluating the Impact on Wages in the UK." London School of Economics. Mimeo, 2006.

Banks, James, Richard Disney, Alan Duncan, and John Van Reenen.

"The Internationalisation of Public Welfare Policy." Economic Journal 115 No. 502 (March, 2005): C62-81.

Baughman, Reagan, and Stacy DickertConlin.

"Did Expanding the EITC Promote Motherhood?" American Economic Review 93 No. 2 (May, 2003): 247-51.

Blundell, Richard, Alan Duncan, Julian

McCrae, and Costas Meghir.

"The Labour Market Impact of the Working Families Tax Credit." Fiscal Studies 21 No. 1 (October, 2000): 65-74.

Blundell, Richard, and Howard Reed.

"The Employment Effects of the Working Families' Tax Credit." Briefing Note No. 6. London: Institute for Fiscal Studies, 2000.

Brewer, Mike.

"The New Tax Credits." Briefing Note No. 35. London: Institute for Fiscal Studies, 2003.

Brewer, Mike, Alan Duncan, Andrew

Shephard, and María José Suárez.

"Did the Working Families Tax Credit Work? Analysing the Impact of In-work Support on Labour Supply and Programme Participation." London: Institute for Fiscal Studies, 2003. http:/ / www.inlandrevenue. gov.uk/research/.

Clarke, Paul, and Pam Tate.

"Methodological Issues in the Production and Analysis of Longitudinal Data from the Labour Force Survey." Government Statistical Service Methodology Series No. 17. London: Office for National Statistics, 1999.

Dickens, Richard, and Alan Manning. "Has The National Minimum Wage Reduced UK Wage Inequality?" London: Centre for Economic Performance, 2002.
Dilnot, Andrew, and Julian McCrae.

"Family Credit and the Working Families' Tax Credit." Briefing Note No. 3. London: Institute for Fiscal Studies, 1999.

Eissa, Nada, and Hilary Hoynes.

"Taxes and the Labor Market Participation of Married Couples: The Earned Income Tax Credit." Journal of Public Economics 88 No. 9-10 (August, 2004): 1931-58.

Eissa, Nada, and Jeffrey Liebman.

"Labor Supply Response to the Earned Income Tax Credit." Quarterly Journal of Economics 111 No. 2 (May, 1996): 605-37.

Ellwood, David T.

"The Impact of the Earned Income Tax Credit and Social Policy Reforms on Work, Marriage, and Living Arrangements." $\mathrm{Na}$ tional Tax Journal 53 No. 4 Part 2 (December, 2000): 1063-105.

Francesconi, Marco, and Wilbert van der

Klaauw.

"The Socioeconomic Consequences of 'In-Work' Benefit Reform for British Lone Mothers." Journal of Human Resources 42 No. 1 (Winter, 2007): 1-31.

Gregg, Paul, and Susan Harkness.

"Welfare Reform and Lone Parents' Employment in the UK." CMPO Working Paper Series No. 03/072. Bristol, United Kingdom: University of Bristol, 2003.

Gregg, Paul, Paul Johnson, and Howard Reed. "Entering Work and the British Tax and Benefit System." Report No. 59. London: Institute for Fiscal Studies, 1999.

Gradus, Raymond.

"Comparing Different European Income Tax Policies Making Work Pay." IFO Studien 47 No. 3 (September, 2001): 311-26.

Hausman, Jerry.

"Taxes and Labor Supply." In Handbook of Public Economics, Vol. 1, edited by Alan J. Auerbach and Martin Feldstein, 213-63. Oxford: Elsevier, 1985.

Inland Revenue.

“Working Families' Tax Credit Statistics. Quarterly Inquiry. United Kingdom. November 2002." London: Inland Revenue, 2003. 
Leigh, Andrew.

"Who Benefits from the Earned Income Tax Credit? Incidence Among Recipients, Coworkers and Firms." Australian National University. Mimeo, 2004.

Machin, Stephen, and Joan Wilson.

"Minimum Wages in a Low-Wage Labour Market: Care Homes in the UK." Economic Journal 114 No. 494 (March, 2004): C102-9.

Meyer, Bruce D.

"Labor Supply at the Extensive and Intensive Margins: The EITC, Welfare, and Hours Worked." American Economic Review 92 No. 2 (May, 2002): 373-9.

Meyer, Bruce D., and Dan T. Rosenbaum.

"Welfare, the Earned Income Tax Credit, and the Labor Supply of Single Mothers." Quarterly Journal of Economics 116 No. 3 (August, 2001): 1063-114.

Michalopoulos, Charles, Philip K. Robins, and David Card.

"When Financial Work Incentives Pay for Themselves: Evidence From a Randomized Social Experiment for Welfare Recipients." Journal of Public Economics 89 No. 1 (January, 2005): 5-29.

Neumark, David, and William Wascher.

"Using the EITC to Help Poor Families: New Evidence and a Comparison with the Minimum Wage." National Tax Journal 54 No. 2 (June, 2001): 281-318.

Office of National Statistics.

"Labour Force Survey Five-Quarter Longitudinal Dataset, December 2001-February 2003, SN 4670." London: ONS, Vol. 11, 2003.

Paull, Gillian, Ian Walker, and Yu Zhu.

"Child Support Reform: Some Analysis of the 1999 White Paper." Fiscal Studies 21 No. 1 (March, 2000): 105-40.

Rothstein, Jesse.

"The Mid-1990s EITC Expansion: Aggregate Labor Supply Effects and Economic Incidence." Princeton University. Mimeo, 2006.

Stewart, Mark B.

"The Employment Effects of the National Minimum Wage." Economic Journal 114 No. 494 (March, 2004): C110-6.
United States Treasury.

"Taxpayers Were Assessed Additional Tax for Advance Earned Income Credit Payments Not Received." Publicly Released Memorandum, Ref. No. 2003-40-126, Washington, D.C., 2003.

\section{APPENDIX}

\section{SPECIFICATION CHECKS}

The empirical findings presented in this paper are based on individual fixed effects regressions. Here, I compare these findings with two alternative specifications: a simple differences-in-differences estimate, and an estimate in which I calculate a matched propensity score for the treatment and control groups, and then calculate the differences-indifferences estimate by weighting each observation by the inverse of its propensity score. Both are calculated for the sample including all adults, and the propensity score is calculated using local linear regression matching, with the variables included in the probit model being gender, age, years of education, race (four categories), and a dummy for single/ non-single.

Appendix Table 1 presents three sets of results-the individual fixed effects specification shown in Table 2 (reproduced here for ease of comparability), a differences-in-differences estimate, and a matched differences-in-differences estimate. Note that in the absence of attrition from the panel, the estimates in Panels A and B should be identical. However, with 3.3 percent of respondents failing to answer the survey in one or more quarters, it is possible that these two estimation methods may have diverged.

The results from Panels A, B and C produce similar results for total hours and earnings, but the positive effect on employment does not recur in either of the differences-in-differences specification. A positive effect on working more than 30 hours is found in the individual fixed effects and matched differences-in-differences specifications, but not in the simple differ- 
ences-in-differences specification, while the positive effect on working more than 16 hours is found only in the matched differences-indifferences specification.

Which set of results should be preferred? The advantage of the individual fixed effects specification over differences-in-differences is that it is possible to distinguish between changes that are due to compositional effects and changes that are due to individuals changing their behavior. For example, the findings in column 1 show that persons in the treatment group were more likely to begin working than those in the control group (Panel A), but the average change in the employment rate of the two groups was statistically indistinguishable (Panels B and C). These findings indicate a higher rate of attrition of employed persons from the treatment group or non-employed persons from the control group. While it is possible that this attrition was non-random, to the extent that it was related to observable characteristics in the attritors, it will be captured by the longitudinal weights. For this reason, the paper focuses on the individual fixed effects specification.

\section{APPENDIX TABLE 1}

FULL SAMPLE

Panel A: Regression with individual fixed effects (same as Table 2)

Treatment group: Parents

Control group: Childless adults

\begin{tabular}{|c|c|c|c|c|c|c|}
\hline & $\begin{array}{c}(1) \\
\text { Employed }\end{array}$ & $\begin{array}{c}(2) \\
\text { Total weekly hours }\end{array}$ & $\begin{array}{c}(3) \\
>16 \text { hours }\end{array}$ & $\begin{array}{c}(4) \\
>30 \text { hours }\end{array}$ & $\begin{array}{c}(5) \\
\text { Log } \\
\text { (pre-tax } \\
\text { earnings) }\end{array}$ & $\begin{array}{c}\text { (6) } \\
\text { Log } \\
\text { (post-tax } \\
\text { earnings) }\end{array}$ \\
\hline Treat*After & $\begin{array}{c}0.009^{*} \\
{[0.005]}\end{array}$ & $\begin{array}{l}1.284^{* * *} \\
{[0.387]}\end{array}$ & $\begin{array}{c}0.025^{* * *} \\
{[0.009]}\end{array}$ & $\begin{array}{l}0.031^{* * *} \\
{[0.010]}\end{array}$ & $\begin{array}{c}0.046^{* * *} \\
{[0.012]}\end{array}$ & $\begin{array}{c}0.033^{* * *} \\
{[0.011]}\end{array}$ \\
\hline After & $\begin{array}{c}-0.008^{* *} \\
{[0.003]}\end{array}$ & $\begin{array}{c}-1.266^{* * *} \\
{[0.270]}\end{array}$ & $\begin{array}{l}-0.008 \\
{[0.006]}\end{array}$ & $\begin{array}{c}-0.028^{* * *} \\
{[0.007]}\end{array}$ & $\begin{array}{c}0.004 \\
{[0.009]}\end{array}$ & $\begin{array}{c}0.01 \\
{[0.007]}\end{array}$ \\
\hline $\begin{array}{l}\text { Indiv. FE? } \\
\mathrm{N} \\
\mathrm{R}^{2}\end{array}$ & $\begin{array}{c}\text { Yes } \\
31,391 \\
0.90\end{array}$ & $\begin{array}{c}\text { Yes } \\
23,625 \\
0.57\end{array}$ & $\begin{array}{c}\text { Yes } \\
23,625 \\
0.69\end{array}$ & $\begin{array}{c}\text { Yes } \\
23,625 \\
0.74 \\
\end{array}$ & $\begin{array}{c}\text { Yes } \\
10,192 \\
0.95\end{array}$ & $\begin{array}{c}\text { Yes } \\
10,084 \\
0.95\end{array}$ \\
\hline \multicolumn{7}{|c|}{ Panel B: Differences-in-differences estimate } \\
\hline DD estimate & $\begin{array}{l}-0.005 \\
{[0.004]}\end{array}$ & $\begin{array}{c}1.015^{* * *} \\
0.197\end{array}$ & $\begin{array}{l}-0.004 \\
{[0.003]}\end{array}$ & $\begin{array}{l}0.0002 \\
{[0.004]}\end{array}$ & $\begin{array}{c}0.027^{* * *} \\
{[0.009]}\end{array}$ & $\begin{array}{l}0.016^{* *} \\
{[0.008]}\end{array}$ \\
\hline \multicolumn{7}{|c|}{ Panel C: Matched differences-in-differences estimate } \\
\hline DD estimate & $\begin{array}{l}-0.004 \\
{[0.005]}\end{array}$ & $\begin{array}{l}1.525^{* * *} \\
{[0.196]}\end{array}$ & $\begin{array}{c}0.041^{* * *} \\
{[0.004]}\end{array}$ & $\begin{array}{l}0.032^{* * *} \\
{[0.005]}\end{array}$ & $\begin{array}{l}0.018^{* *} \\
{[0.009]}\end{array}$ & $\begin{array}{c}0.010 \\
{[0.008]}\end{array}$ \\
\hline
\end{tabular}

Note: ${ }^{* * *},{ }^{* *}$ and ${ }^{*}$ denote significance at the $1 \%, 5 \%$ and $10 \%$ levels, respectively. Robust standard errors, clustered at the individual level, are in parentheses. Specifications including work hours are restricted to those in employment. Earnings are combined weekly earnings from main job and any secondary job. Post-tax earnings take into account income taxes and tax credits. In Panel A, "Treat" denotes individuals in the treatment group, while "After" denotes observations after October 1999. 